\title{
Local Contractors' Awareness on Competitiveness towards Liberalisation and Globalisation in the Malaysian Construction Industry
}

\author{
"Nur Izzati Ab. Rani, Syuhaida Ismail, Zainai Mohamed, Afifuddin Husairi \\ Hussain and Kambiz Ghafourian
}

\begin{abstract}
Published online: 31 August 2018
To cite this article: Nur Izzati Ab Rani, Syuhaida Ismail, Zainai Mohamed, Afifuddin Husairi Hussain and Kambiz Ghafourian (2018). Local contractors' awareness on competitiveness towards liberalisation and globalisation in the Malaysian construction
\end{abstract} industry. Journal of Construction in Developing Countries, 23(1): 21-42. https://doi.org/10.21315/jcdc2018.23.1.2.

To link to this article: https://doi.org/10.21315/jcdc2018.23.1.2

\begin{abstract}
Globalisation gives the opportunity to contractors from a particular country to venture into various countries around the globe as the construction market is unlimitedly open. Due to this globalisation, the government has signed free trade agreements (FTA) as the result of the liberalisation process. Globalisation and liberalisation do not only provide opportunities and benefits to the local construction market, but also give challenges to local contractors in terms of competition with other local and foreign contractors. Yet, a question arises whether the local contractors in particular are aware with the competitive challenges they are facing against the foreign contractors or even amongst the local contractors themselves. This is because there are limited studies conducted which seek to identify the current levels of awareness on competitiveness among local contractors within the Malaysian construction industry. Hence, this paper emerges with the objectives of (1) identifying the current level of awareness of local contractors on competitiveness and (2) investigating the most important attributes of awareness of local contractors in the Malaysian construction industry. Questionnaire surveys were conducted on local Malaysian contractors involving 61 organisations from 112 venturing into overseas market. Data were analysed via Rasch analysis consisting of five method analysis which are the reliability and validity analysis, organisation misfit analysis, unidimensionality analysis, item misfit analysis and item measure order analysis. Findings from this paper reveal that most of the contractors have a moderate level of awareness on the competitiveness in the Malaysian construction industry. The findings of this study have been concluded as the local contractors acknowledge their competitors' strength and weaknesses when bidding for new projects and also aim to improve their competitiveness in competing with other local contractors locally. Recognition of this paper on the awareness of the importance of competitiveness by various local contractors in the Malaysian construction industry is in line with the Construction Industry Transformation Plan (CITP) 2016-2020 in addressing the Internationalisation Thrust with the aim to increase competitiveness of the domestic market, especially with the presence of foreign players.
\end{abstract}

Keywords: Awareness, Competitiveness, Local contractors, Malaysian construction industry, Globalisation, Liberalisation

\section{INTRODUCTION}

In globalisation, capital and labour mobility have increased the economic and market interdependence among countries. It has also linked world production in

Razak School of Engineering and Advanced Technology, Universiti Teknologi Malaysia (UTM), Kuala Lumpur, MALAYSIA

"Corresponding author: atirani_civil@yahoo.com

(C) Penerbit Universiti Sains Malaysia, 2018. This work is licensed under the terms of the Creative Commons Attribution (CC BY) (http://creativecommons.org/licenses/by/4.0/). 
supply chains and has connected more countries due to reduced trade barriers and greater competition. Nevertheless, in terms of costs, global market threats can be destructive to firm performance because of the increasing intensity of competitors (Chaiprasit and Swierczek, 2011). Competitiveness is seen as a result of the global economic crisis that affects normal operations of construction companies. This is proven true when Shan (2010) claimed that local Chinese firms should be aware of the fierce competition that foreign firms would give them in China when more market liberalisation takes place.

It is also previously found that, contractors had to compete against three or four companies between local contractors, but now during the globalisation and liberalisation crisis, they are competing against ten or more (Orozco, Serpell and Molenaar, 2011). Furthermore, Wong (2012) claimed that due to the implementation of the General Agreement on Trade in Services (GATS) and the liberalisation of the engineering consulting services (ECS) sector, the Malaysian ECS industry will no longer be fully protected by legislations in the domestic market from foreign competition, although existing prohibitive legislations and protective barriers could be changed. Thus, there is a need for members to understand the likely impact of ASEAN Free Trade Area (AFTA) on their businesses and to prepare themselves for competition with foreign firms (Majid et al., 2004).

According to Malaysian practice, there are two types of free trade agreements (FTA) under the construction and related engineering services, which are the regional FTA and bilateral FTA as mentioned by the Construction Development Board (CIDB) (CIDB, 2014). In regional FTA, there are six FTA, which are the ASEAN Framework Agreement in Services (AFAS), ASEAN-China Free Trade Area (ACFTA), ASEAN-Japan Comprehensive Economic Partnership (AJCEP), ASEAN-Australia/New Zealand (AANZFTA), ASEAN-Korea Free Trade Area (AKFTA) and ASEAN-India Trade in Goods Agreement (AITIGA). As for bilateral FTA where the agreement will benefit both the host and home country, there are seven FTA in bilateral FTA which are the Malaysia-Japan Economic Partnership Agreement (MJEPA), Malaysia-Pakistan Comprehensive Economic Partnership Agreement (MPCEPA), Malaysia-New Zealand Free Trade Agreement (MNZFTA), MalaysiaAustralia Free Trade Agreement (MAFTA), Malaysia-India Comprehensive Economic Cooperation Agreement (MICECA), Malaysia-Chile Free Trade Agreement (MCFTA) and Malaysia-Turkey Free Trade Agreement (MTFTA).

According to the FTA signed by the Malaysian government as the result of globalisation and liberalisation, it is important to identify the current awareness of local contractors in competing with local and foreign contractors in the Malaysian construction industry, which is expected to be achieved by this paper as discussed in the following section.

\section{AWARENESS ON COMPETITIVENESS}

Henricsson et al. (2004) defined "competitiveness" as an aggressive willingness to compete. Costa, Singh and El-Diraby (2006) further referred to company competitiveness as its ability to design, produce and market products better than offered by their competitors. On the other hand, Orozco et al. (2014) briefed competitiveness as to having better abilities and capabilities than competitors by involving both the results achieved in the past and the perception of the future potential of a company. 
Significant studies have been carried out particularly in China, where Sha, Yang and Song (2008) found out that when the Chinese opens their construction market to foreign contractors due to their commitment to the World Trade Organisation (WTO), the competition in the construction market leads to the growth of awareness on the need to study on how to enhance the competitiveness in the Chinese construction industry.

Nevertheless, as for Malaysia, there is currently limited study being carried out on this matter. Further studies in China include Zhao and Shen (2008) who conducted a study on how Chinese contractors of the Republic of China (ROC) compete in the international markets. It is claimed by Zhao and Shen (2008) that when the Chinese contractors enlarge their business in the host country, the other foreign contractors in the host country also have high awareness on the Chinese contractors' competitiveness. It is therefore important for the foreign contractors to know the advantages, weaknesses and characteristics of the Chinese contractors to maintain their competitive position. Gauging against the Chinese construction industry, it is observed by this paper that local Malaysian contractors too must have high awareness level of competitiveness of current situation in the Malaysian construction industry. Thus, it is important to investigate factors contributing to competitiveness in the Malaysian construction industry. It is suggested by this paper that local contractors must set up their readiness towards competition on the challenges to compete with other local and foreign contractors, finally adopting the competitive strategy in competing with their competitors.

In line with this suggestion, more actions are recommended by the stakeholders through education programmes, such as training courses, conferences, seminars, study tour, public announcement and workshops in order to increase the awareness and knowledge level (Alsanad, Gale and Edwards, 2011). For instance, Yates and Aniftos (1997) claimed that the United States (US) construction industry has increased its awareness level and become more actively involved in the development and implementation of international standards, which eventually impacts on the international competitiveness of the industry. As stated by Yean et al. (2009), awareness of new challenges in their environment in the Vietnamese construction industry also allows them to be better prepared.

Table 1 summarises the items for the awareness of the competitiveness of the local contractors in the Malaysian construction industry. All the items were extracted from previous literature review. All the items were used to identify the current awareness level and investigate the important attributes of awareness of local contractors on competitiveness in the Malaysian construction industry via a questionnaire survey.

Hence, this paper suggests that local contractors in the Malaysian construction must also take significant action to secure their position in competing with foreign contractors and even amongst the other local contractors in the Malaysian construction industry as the country is moving towards liberalisation and globalisation. 
Table 1. Items for Awareness of the Competitiveness of the Local Contractors in the Malaysian Construction Industry

\begin{tabular}{|c|c|c|}
\hline No. & Items & References \\
\hline 1 & $\begin{array}{l}\text { Local contractors have adequate information on FTA in } \\
\text { Malaysia. }\end{array}$ & $\begin{array}{l}\text { Alsanad, Gale and } \\
\text { Edwards (2011), CIDB } \\
\text { (2013) }\end{array}$ \\
\hline 2 & $\begin{array}{l}\text { Local contractors are seen to attend any education } \\
\text { programs by government to increase knowledge on } \\
\text { FTA. }\end{array}$ & $\begin{array}{l}\text { Alsanad, Gale and } \\
\text { Edwards (2011), CIDB } \\
\text { (2013) }\end{array}$ \\
\hline 3 & $\begin{array}{l}\text { Local contractors are seen to attend any education } \\
\text { programs by non-government to increase knowledge } \\
\text { on FTA. }\end{array}$ & $\begin{array}{l}\text { Alsanad, Gale and } \\
\text { Edwards (2011), CIDB } \\
\text { (2013) }\end{array}$ \\
\hline 4 & $\begin{array}{l}\text { Local contractors identify competitiveness of } \\
\text { competitor characteristics when bidding new projects. }\end{array}$ & $\begin{array}{l}\text { Oo, Drew and } \\
\text { Runeson (2010) }\end{array}$ \\
\hline 5 & $\begin{array}{l}\text { Local contractors identify competitiveness of } \\
\text { competitor strength when bidding new projects. }\end{array}$ & $\begin{array}{l}\text { Wang, Xu and Li } \\
\text { (2009), Enshassi, } \\
\text { Mohamed and Karriri } \\
\text { (2010) }\end{array}$ \\
\hline 6 & $\begin{array}{l}\text { Local contractors identify competitiveness of } \\
\text { competitor weaknesses when bidding new projects. }\end{array}$ & $\begin{array}{l}\text { Bose (2008), Tung } \\
\text { (2012) }\end{array}$ \\
\hline 7 & $\begin{array}{l}\text { Local contractors increase level of readiness in } \\
\text { competing with other local contractors locally. }\end{array}$ & $\begin{array}{l}\text { Dlungwana and } \\
\text { Rwelamila (2004) }\end{array}$ \\
\hline 8 & $\begin{array}{l}\text { Local contractors increase level of readiness in } \\
\text { competing with foreign contractors locally. }\end{array}$ & Majid et al. (2004) \\
\hline 9 & $\begin{array}{l}\text { Local contractors improve competitiveness in } \\
\text { competing with other local contractors locally. }\end{array}$ & $\begin{array}{l}\text { Lu et al. (2009), } \\
\text { Suresh and Egbu } \\
\text { (2007), Ling and Gui } \\
\text { (2009) }\end{array}$ \\
\hline 10 & $\begin{array}{l}\text { Local contractors improve competitiveness in } \\
\text { competing with foreign contractors locally. }\end{array}$ & $\begin{array}{l}\text { Yu (2003), Suresh and } \\
\text { Egbu (2007), Lu et al. } \\
\text { (2009) }\end{array}$ \\
\hline 11 & $\begin{array}{l}\text { Local contractors implement competitive strategy in } \\
\text { competing with other local contractors. }\end{array}$ & $\begin{array}{l}\text { Abidin, Adros and } \\
\text { Hassan (2014) }\end{array}$ \\
\hline 12 & $\begin{array}{l}\text { Local contractors implement competitive strategy in } \\
\text { competing with foreign contractors. }\end{array}$ & $\begin{array}{l}\text { Abidin, Adros and } \\
\text { Hassan (2014) }\end{array}$ \\
\hline 13 & $\begin{array}{l}\text { Local contractors focus on improving competitiveness } \\
\text { in the capability and capacity to venture } \\
\text { internationally. }\end{array}$ & $\begin{array}{l}\text { Li, Li and Dalgic } \\
\text { (2004), Ministry of } \\
\text { International Trade } \\
\text { and Industry (MITI) } \\
\text { (2006) }\end{array}$ \\
\hline 14 & $\begin{array}{l}\text { Local contractors more aware of technological } \\
\text { changes occurring outside the industry that can be } \\
\text { applied to competing in it. }\end{array}$ & $\begin{array}{l}\text { Winch (2000), Seaden } \\
\text { and Manseau (2001), } \\
\text { Sher and Lee (2004), } \\
\text { Yu et al. (2006) }\end{array}$ \\
\hline
\end{tabular}


Table 1. (continued)

\begin{tabular}{|c|c|c|}
\hline No. & Items & References \\
\hline 15 & $\begin{array}{l}\text { Local contractors form strategic partnerships with } \\
\text { multinational companies (MNCs) and government } \\
\text { linked companies (GLCs) to gain access to local and } \\
\text { international markets. }\end{array}$ & $\begin{array}{l}\text { Economic Planning } \\
\text { Unit (EPU) (2015) }\end{array}$ \\
\hline 16 & $\begin{array}{l}\text { Local contractors raise the awareness of the benefit of } \\
\text { new knowledge, technology availability in the market } \\
\text { and improving the accessibility of new knowledge. }\end{array}$ & $\begin{array}{l}\text { Kamal and Flanagan } \\
(2012)\end{array}$ \\
\hline 17 & $\begin{array}{l}\text { Awareness by local contractors about the } \\
\text { competitiveness of their competitor is growing. }\end{array}$ & Sha et al. (2008) \\
\hline 18 & $\begin{array}{l}\text { Local contractors classify the types of competition that } \\
\text { they face. }\end{array}$ & $\begin{array}{l}\text { Bergen and Peteraf } \\
(2002)\end{array}$ \\
\hline 19 & $\begin{array}{l}\text { Local contractors are aware of the fierce competition } \\
\text { that other local and foreign contractors would give } \\
\text { them in Malaysia when more market liberalisation takes } \\
\text { place. }\end{array}$ & Shan (2010) \\
\hline 20 & $\begin{array}{l}\text { Local contractors develop an awareness of the primary } \\
\text { importance of competitive strategy in pursuit of } \\
\text { competitive advantage. }\end{array}$ & Lu et al. (2008) \\
\hline 21 & $\begin{array}{l}\text { Local contractors are aware of the importance of } \\
\text { effective implementation of strategy in improving } \\
\text { competitiveness. }\end{array}$ & Lu et al. (2008) \\
\hline 22 & $\begin{array}{l}\text { Local contractors are aware of the fundamental role } \\
\text { played by innovation in achieving competitive success. }\end{array}$ & $\begin{array}{l}\text { Pellicer, Yepes and } \\
\text { Rojas (2010) }\end{array}$ \\
\hline
\end{tabular}

Figure 1 illustrates the theoretical framework of local contractors' competitiveness in the Malaysian construction industry. There are 5 constructs in the theoretical framework, namely competitiveness awareness, competitiveness factors, driver of competitiveness, competitiveness challenges and competitiveness strategy. However, this study is limited to the construct on awareness of competitiveness in the Malaysian construction industry.

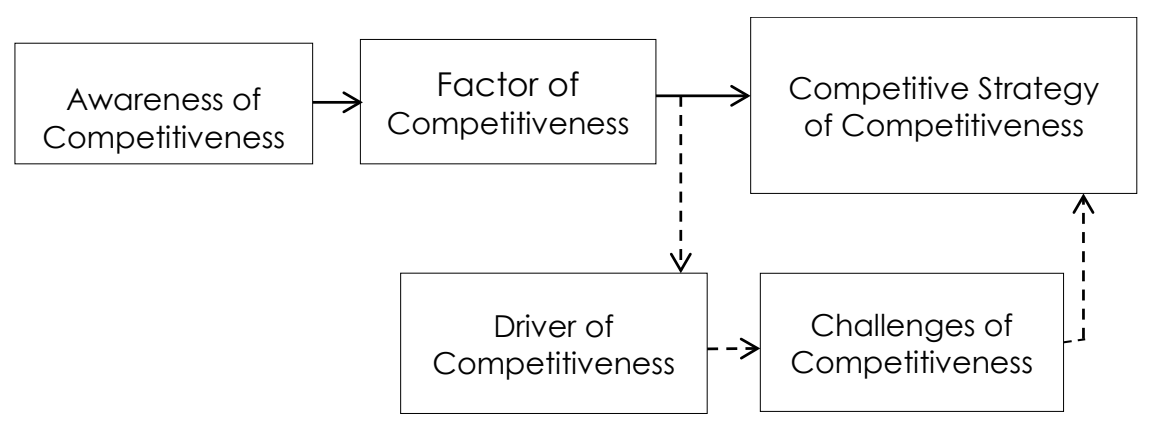

Figure 1. Theoretical Framework of Local Contractors' Competitiveness in the Malaysian Construction Industry 


\section{METHODOLOGY}

\section{Population and Sampling Design}

This study was conducted on Malaysian contractors registered with the Construction Industry Development Board (CIDB) who have ventured overseas. This is because local contractors who are working overseas are expected to have more experience in working with foreign contractors in the host. In competing with foreign and local contractors in the Malaysian construction industry, contractors have to identify and improve their competitive areas.

According to CIDB (2016b), there are 112 local contractors working overseas since 1986 until now. They are working in many scopes of work, such as building, residential, mixed development, highway, airport, transmission, railway, power plant, road, building commercials, jetty port, mechanical and electrical and others. These local contractors are also working in many countries of the main region, such as South Asia, ASEAN, Middle East, Africa and others, with the total value of projects ranging between RM100,000 and RM1 1 billion, based on their total value of projects from year 1986 until December 2015 (Ab Rani, Mat Isa and Preece, 2015). This questionnaire survey was therefore conducted using these local contractors from the CIDB database as the respondents for this study.

\section{Questionnaire Design}

The survey required respondents to represent their organisation in providing responses based on the level of awareness on competitiveness in the Malaysian construction industry. The self-developed questionnaire survey comprised of 22 items as shown in Table 2, which identified the current level of awareness of local contractors on competitiveness in the Malaysian construction industry towards liberalisation and globalisation. This is to know how the local contractors compete with local and foreign contractors in the Malaysian construction industry. All 22 items used the fivepoint Likert scale points, which reflect the level of their organisation awareness as: 1 = Not at all aware, 2 = Slightly aware, 3 = Somewhat aware, 4 = Moderately aware and $5=$ Extremely aware.

Table 2. Items Construct for Awareness of the Competitiveness of the Local Contractors in the Malaysian Construction Industry

\begin{tabular}{lll}
\hline No. & \multicolumn{1}{c}{ Items } & \multicolumn{1}{c}{ Coding } \\
\hline 1 & $\begin{array}{l}\text { Local contractors have adequate information on free trade } \\
\text { agreements (FTA) in Malaysia. }\end{array}$ & B1_info_fta \\
2 & $\begin{array}{l}\text { Local contractors are seen to attend any education programs by } \\
\text { government to increase knowledge on FTA. }\end{array}$ & $\begin{array}{l}\text { B2_edu_ } \\
\text { gov_fta }\end{array}$ \\
3 & $\begin{array}{l}\text { Local contractors are seen to attend any education programs by } \\
\text { non-government to increase knowledge on FTA. }\end{array}$ & $\begin{array}{l}\text { B3_edu_non- } \\
\text { gov_fta }\end{array}$
\end{tabular}


Table 2. (continued)

\begin{tabular}{|c|c|c|}
\hline No. & Items & Coding \\
\hline 4 & $\begin{array}{l}\text { Local contractors identify competitiveness of competitor } \\
\text { characteristics when bidding new projects. }\end{array}$ & $\begin{array}{l}\text { B4_comp_ } \\
\text { charact }\end{array}$ \\
\hline 5 & $\begin{array}{l}\text { Local contractors identify competitiveness of competitor strength } \\
\text { when bidding new projects. }\end{array}$ & $\begin{array}{l}\text { B5_comp_ } \\
\text { strength }\end{array}$ \\
\hline 6 & $\begin{array}{l}\text { Local contractors identify competitiveness of competitor } \\
\text { weaknesses when bidding new projects. }\end{array}$ & $\begin{array}{l}\text { B6_comp_ } \\
\text { weak }\end{array}$ \\
\hline 7 & $\begin{array}{l}\text { Local contractors increase level of readiness in competing with } \\
\text { other local contractors locally. }\end{array}$ & $\begin{array}{l}\text { B7_readiness } \\
\text { _local }\end{array}$ \\
\hline 8 & $\begin{array}{l}\text { Local contractors increase level of readiness in competing with } \\
\text { foreign contractors locally. }\end{array}$ & $\begin{array}{l}\text { B8_readiness } \\
\text { foreign }\end{array}$ \\
\hline 9 & $\begin{array}{l}\text { Local contractors improve competitiveness in competing with } \\
\text { other local contractors locally. }\end{array}$ & $\begin{array}{l}\text { B9_imprv_ } \\
\text { local }\end{array}$ \\
\hline 10 & $\begin{array}{l}\text { Local contractors improve competitiveness in competing with } \\
\text { foreign contractors locally. }\end{array}$ & $\begin{array}{l}\text { B10_imprv_ } \\
\text { foreign }\end{array}$ \\
\hline 11 & $\begin{array}{l}\text { Local contractors implement competitive strategy in competing } \\
\text { with other local contractors. }\end{array}$ & $\begin{array}{l}\text { B11_implem_ } \\
\text { local }\end{array}$ \\
\hline 12 & $\begin{array}{l}\text { Local contractors implement competitive strategy in competing } \\
\text { with foreign contractors. }\end{array}$ & $\begin{array}{l}\text { B12_implem } \\
\text { foreign }\end{array}$ \\
\hline 13 & $\begin{array}{l}\text { Local contractors focus on improving competitiveness in the } \\
\text { capability and capacity to venture internationally. }\end{array}$ & $\begin{array}{l}\text { B13_capab_ } \\
\text { capac }\end{array}$ \\
\hline 14 & $\begin{array}{l}\text { Local contractors more aware of technological changes occurring } \\
\text { outside the industry that can be applied to competing in it. }\end{array}$ & B14_techno \\
\hline 15 & $\begin{array}{l}\text { Local contractors form strategic partnerships with multinational } \\
\text { companies (MNCs) and government linked companies (GLCs) to } \\
\text { gain access to local and international markets. }\end{array}$ & $\begin{array}{l}\text { B15_- } \\
\text { partnerships }\end{array}$ \\
\hline 16 & $\begin{array}{l}\text { Local contractors raise the awareness of the benefit of new } \\
\text { knowledge, technology availability in the market and improving } \\
\text { the accessibility of new knowledge. }\end{array}$ & $\begin{array}{l}\text { B16_raise_- } \\
\text { aware }\end{array}$ \\
\hline 17 & $\begin{array}{l}\text { Awareness by local contractors about the competitiveness of their } \\
\text { competitor is growing. }\end{array}$ & B17_grow \\
\hline 18 & Local contractors classify the types of competition that they face. & $\begin{array}{l}\text { B18_classify_ } \\
\text { type }\end{array}$ \\
\hline 19 & $\begin{array}{l}\text { Local contractors are aware of the fierce competition that other } \\
\text { local and foreign contractors would give them in Malaysia when } \\
\text { more market liberalisation takes place. }\end{array}$ & $\begin{array}{l}\text { B19_fierce_ } \\
\text { compe }\end{array}$ \\
\hline
\end{tabular}


Table 2. (continued)

\begin{tabular}{cll}
\hline No. & \multicolumn{1}{c}{ Items } & \multicolumn{1}{c}{ Coding } \\
\hline 20 & $\begin{array}{l}\text { Local contractors develop an awareness of the primary } \\
\text { importance of competitive strategy in pursuit of competitive } \\
\text { advantage. }\end{array}$ & $\begin{array}{l}\text { B20_comp_ } \\
\text { strategy }\end{array}$ \\
21 & $\begin{array}{l}\text { Local contractors are aware of the importance of effective } \\
\text { implementation of strategy in improving competitiveness. }\end{array}$ & $\begin{array}{l}\text { B21_effect_ } \\
\text { imp }\end{array}$ \\
22 & $\begin{array}{l}\text { Local contractors are aware of the fundamental role played by } \\
\text { innovation in achieving competitive success. }\end{array}$ & $\begin{array}{l}\text { B22__ } \\
\text { fundamental }\end{array}$ \\
\hline
\end{tabular}

\section{Analysis}

All the data gathered from the questionnaire survey were analysed via the Rasch model using WINSTEPS version 3.69.1.16 software. Rasch model analysis was used because the model changes the concept of reliability from creating a line of fit of the data into constructing a reliable measurement instrument (Said, 2016). Baghaei (2008) stated that one of the advantages of the Rasch model is that it builds a hypothetical unidimensional line along which items and persons are located according to their difficulty and ability measures, which is shown in the Person Item Distribution Map (PIDM). As mentioned by (Bond and Fox, 2001), the Rasch model is a prescriptive model in which we investigate how the data fits the model instead of the more classical statistical problem of how the model fits the data. Scholten (2011) further explained that the data are required to fit the model and when they do not, items that show misfit are discarded until a satisfactory fit is obtained.

The Rasch analysis is done following Bond and Fox (2007) who explain that the logic value used in Rasch model is the unit of measurement at an interval level instead of the ordinary number. Thus, in Rasch model analysis, summary statistic, item characteristic curve scalogram, PIDM and person and item measure order are used. The analysis shows both person and item measures to indicate that the person as the respondent in completing the survey understands the questions given, while the item in the survey is understood and answered by the respondent.

One of the examples of studies using Rasch analysis is by Othman et al. (2014), who assessed construct validity and reliability of the competitiveness scale using The Rasch model approach. The study used the competitiveness scale of Malaysian Higher Education Institutions and the items were quantitatively analysed using the WINSTEPS software 3.72.3 based on the Rasch model to assess the suitability of items. Previously, Huang and Peng (2012) used the Rasch model in Technique for Order Preference by Similarity to Ideal Solution (TOPSIS) to analyse the Tourism Destination Competitiveness (TDC) of nine Asian countries: China, Hong Kong, Japan, Korea, Malaysia, Singapore, Taiwan, Thailand and the Philippines. From the data collected, the fuzzy weights of the TDC criteria were generated with the Rasch model. 


\section{RESULTS}

\section{Response Rate}

According to Krejcie and Morgan (1970), the required sample size is 86 responses from the total population of 112 international Malaysian organisations venturing overseas projects as shown in Table 3. The response rate for the survey is shown in Table 4. It took three months to receive the feedback of 91 out of 112 respondents from March until May 2016. Only 67\% ( $n=61)$ were valid while 35\% ( $n=30$ ) were invalid responses because of incomplete answers given.

Table 3. Determining Sample Size from a Given Population

\begin{tabular}{cc}
\hline Population Sample Size (N) & Required Sample Size (S) \\
\hline 80 & 66 \\
85 & 70 \\
90 & 73 \\
95 & 76 \\
100 & 80 \\
110 & 86 \\
120 & 92 \\
130 & 97 \\
\hline
\end{tabular}

Source: Krejcie and Morgan (1970)

Table 4. Response Rate

\begin{tabular}{lcc}
\hline Categories & Respondent & Percentage (\%) \\
\hline Total respondent & 97 & 100 \\
Incomplete respondent & 36 & 37 \\
Total usable respondent & 61 & 63 \\
\hline
\end{tabular}

\section{Sample Characteristic}

In the demography analysis of the respondents, most of the organisations are in the G7 grade as registered with the CIDB with 36 organisations (59\%) as shown in Figure 2. It showed that the majority of the organisations are well-established organisations in the Malaysian construction industry with strong financial capability, no tendering capacity limit and have paid capital at least RM750,000 as claimed by CIDB (2016a).

According to the type of work which the respondents are involved with, most of the organisations are working in general building projects (62\%) as shown in Figure 3.

As shown in Figure 4, most of the organisations (50\%) have more than 21 years of operational experience in the Malaysian construction industry. The same goes to 
the years of international experience of the organisations, which also recorded the highest percentage (39\%) at having more than 21 years of experience as shown in Figure 5. This showed that most of the organisations as the respondents have the capability in contributing significant responses to this survey.

\section{Organisation Registered Grade with CIDB}

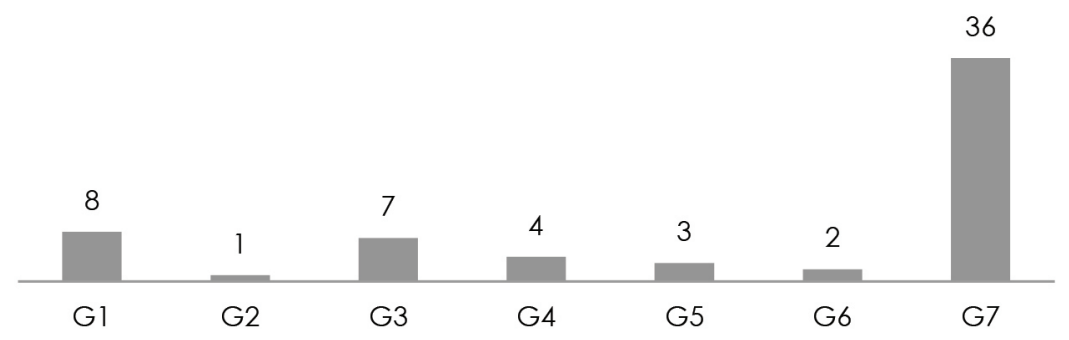

Figure 2. Number of Organisations' Registered Grade with CIDB

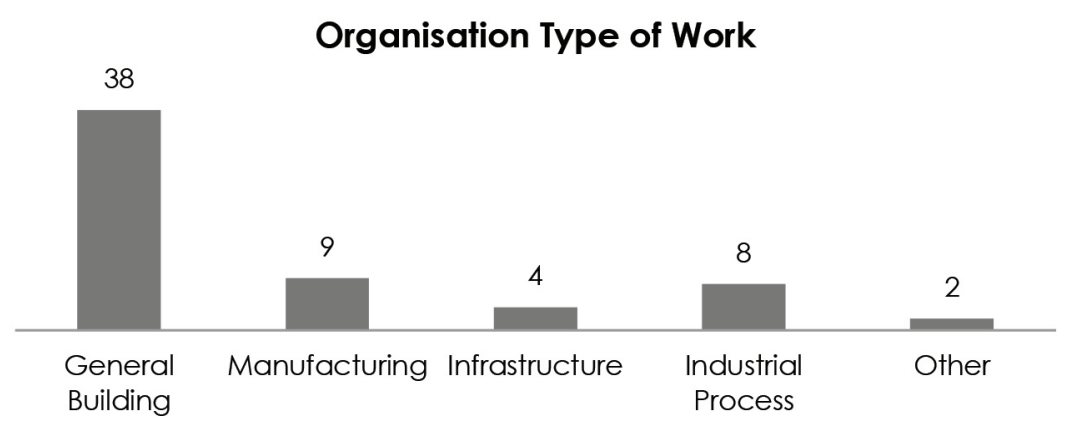

Figure 3. Organisations' Types of Work

\section{Organisation's Operational Experience}

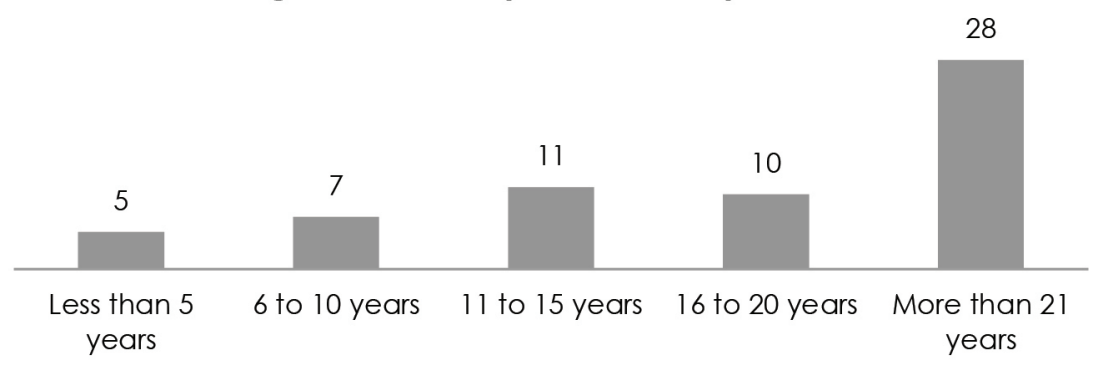

Figure 4. Years of Organisations' Operational Experience 


\section{Organisational International Experience}

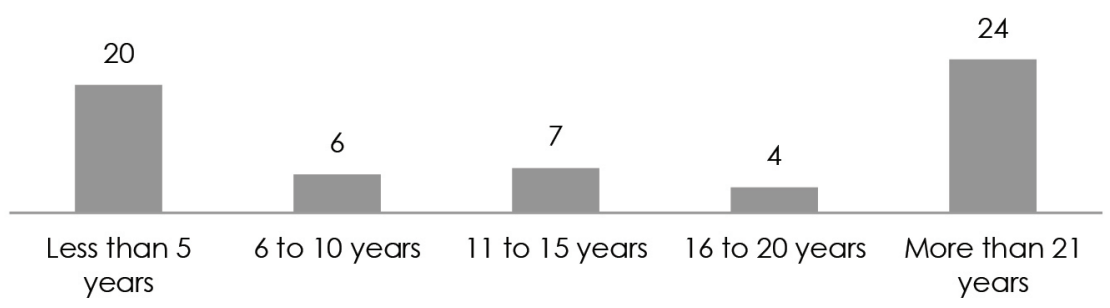

Figure 5. Years of Organisations' International Experience

\section{Data Acquisition}

The survey which used 21 items yielded a total of 1,110 data points from 61 respondents. This suggested that the data provided a large range to remain useful and stable as organisation measure estimates and to obtain useful and stable item calibrations. An approximate reliability test based on the log-likelihood chi square was 1,954.60 with 1,026 degrees of freedom, $p=.0000$. The Cronbach alpha (a) value was 0.98 , indicating good internal consistency for the reliability of items in the scale in measuring a single latent trait or construct.

\section{Organisation and Item Reliability}

In Rasch analysis, both organisation and item reliability were measured. Table 5 demonstrates that the reliability for organisation is $\beta_{\text {org }}=0.96$ with the Standard Error (SE) at 0.29. This indicated that the instrument had an excellent ability range with sufficient rating length scale due adequate number of categories per items and exceptional target respondents as shown in Table 6. Outfit for Mean Square (OMNSQ) and Z-Score (OZSTD) was investigated for further fit statistic investigation. OMNSQ and OZSTD were therefore required to identify the outlier sensitive by unexpected behaviour by the organisation on the items. The OMNSQ was 1.01 and OZSTD was -.4, close to the expected values of 1 and 0 , respectively.

Linacre (2002) indicated the value for Mean-Square value (MNSQ) 0.5 to 1.5 as the productive for measurement and the implication for measurement, while for the Standardised Value (ZSTD) value, -1.9 to 1.9 is the implication for measurement where data have reasonable predictability (Linacre, 2002). The accepted range of MNSQ and ZSTD revealed that the 22 items in the survey were targeting the right respondents in measuring the latent traits and the data yielded were at a reasonable level in predicting the pattern of responses to the items.

In Table 5, the item reliability is $\mu_{\text {item }}=0.87$ with $\mathrm{SE}=0.15$, suggesting that the instrument has good fit to the model (Fisher, 2007). The high item reliability indicated that the replicability of the items would occur if these items were tested by other respondents of the same size (Bond and Fox, 2007). The item mean was set to 0.00 logit to ensure each of the organisations had a 50:50 chance of success in responding to the item to match their ability (Hussain et al., 2015; Intezar, Alotaibi and Abdallah, 
2016). The OMNSQ was 1.01 and OZSTD was -0.2 , close to the expected value of 1 and 0 , respectively. It indicated an excellent match of item-organisation, where the items targeted the person distribution well.

Table 5. Summary of 50 Measured (Non-Extreme) Persons to Identify the Current Awareness of Local Contractors on Competitiveness in the Malaysian Construction Industry

\begin{tabular}{|c|c|c|c|c|c|c|c|c|}
\hline & \multirow{2}{*}{$\begin{array}{l}\text { Total } \\
\text { Score }\end{array}$} & \multirow{2}{*}{ Count } & \multirow{2}{*}{ Measure } & \multirow{2}{*}{$\begin{array}{l}\text { Model } \\
\text { Error }\end{array}$} & \multicolumn{2}{|c|}{ Infit } & \multicolumn{2}{|c|}{ Outfit } \\
\hline & & & & & MNSQ & ZSTD & MNSQ & ZSTD \\
\hline Mean & 81.0 & 22.0 & 1.65 & .36 & 1.05 & -.3 & 1.01 & -.4 \\
\hline SD & 18.1 & .0 & 2.06 & .05 & .73 & 2.3 & .68 & 2.2 \\
\hline Max. & 104.0 & 22.0 & 4.67 & .48 & 3.30 & 5.2 & 2.94 & 4.4 \\
\hline \multirow[t]{3}{*}{ Min. } & 32.0 & 22.0 & -3.79 & .31 & .18 & -4.3 & .18 & -4.4 \\
\hline & Real SMSE & .41 & True SD & 2.02 & Separation & 4.89 & $\begin{array}{l}\text { Person } \\
\text { Reliability }\end{array}$ & .96 \\
\hline & Model SE & .36 & True SD & 2.03 & Separation & 5.63 & $\begin{array}{l}\text { Person } \\
\text { Reliability }\end{array}$ & .97 \\
\hline
\end{tabular}

Table 6. Rating Scale Instrument Quality Criteria

\begin{tabular}{|c|c|c|c|c|c|}
\hline Criterion & Poor & Fair & Good & Very Good & Excellent \\
\hline Targeting* & $>2$ errors & $1-2$ errors & $<1$ error & $<.5$ error & $<.25$ error \\
\hline $\begin{array}{l}\text { Item model fit mean- } \\
\text { square range extremes }\end{array}$ & $\begin{array}{l}<.33- \\
>3.0\end{array}$ & $.34-2.9$ & $.5-2.0$ & $.71-1.4$ & $.77-1.3$ \\
\hline $\begin{array}{l}\text { Person and item } \\
\text { measurement reliability }\end{array}$ & $<.67$ & $.67-.80$ & $.81-.90$ & $.91-.94$ & $>.94$ \\
\hline $\begin{array}{l}\text { Person and item strata } \\
\text { separated }\end{array}$ & 2 or less & $2-3$ & $3-4$ & $4-5$ & $>5$ \\
\hline $\begin{array}{l}\text { Ceiling effect: \% maximum } \\
\text { extreme scores }\end{array}$ & $>5 \%$ & $2 \%-5 \%$ & $1 \%-2 \%$ & $.5 \%-1 \%$ & $<.5 \%$ \\
\hline $\begin{array}{l}\text { Floor effect: \% minimum } \\
\text { extreme scores }\end{array}$ & $>5 \%$ & $2 \%-5 \%$ & $1 \%-2 \%$ & $.5 \%-1 \%$ & $<.5 \%$ \\
\hline $\begin{array}{l}\text { Variance in data } \\
\text { explained by measures }\end{array}$ & $<50 \%$ & $50 \%-60 \%$ & $\begin{array}{l}60 \%- \\
70 \%\end{array}$ & 70\%-80\% & $>80 \%$ \\
\hline $\begin{array}{l}\text { Unexplained variance in } \\
\text { contrasts } 1-5 \text { of PCA of } \\
\text { residuals }\end{array}$ & $>15 \%$ & $10 \%-15 \%$ & $5 \%-10 \%$ & $3 \%-5 \%$ & $<3 \%$ \\
\hline
\end{tabular}


Table 7. Summary of 22 Measured (Non-Extreme) Items to Identify the Current Awareness of Local Contractors on Competitiveness in the Malaysian Construction Industry

\begin{tabular}{|c|c|c|c|c|c|c|c|c|}
\hline & \multirow{2}{*}{$\begin{array}{l}\text { Total } \\
\text { Score }\end{array}$} & \multirow{2}{*}{ Count } & \multirow{2}{*}{ Measure } & \multirow{2}{*}{$\begin{array}{l}\text { Model } \\
\text { Error }\end{array}$} & \multicolumn{2}{|l|}{ Infit } & \multicolumn{2}{|c|}{ Outfit } \\
\hline & & & & & MNSQ & ZSTD & MNSQ & ZSTD \\
\hline Mean & 189.1 & 51.0 & .00 & .23 & 1.01 & -.2 & 1.01 & -.2 \\
\hline SD & 13.4 & .0 & .71 & .01 & .48 & 2.2 & .51 & 2.3 \\
\hline Max. & 209.0 & 51.0 & 1.39 & .25 & 2.52 & 5.6 & 2.54 & 5.6 \\
\hline \multirow[t]{3}{*}{ Min. } & 162.0 & 51.0 & -1.11 & .22 & .45 & -3.3 & .44 & -3.4 \\
\hline & al SMSE & .25 & True SD & .66 & Separation & 2.61 & $\begin{array}{l}\text { Person } \\
\text { Reliability }\end{array}$ & .87 \\
\hline & odel SE & .23 & True SD & .67 & Separation & 2.87 & $\begin{array}{l}\text { Person } \\
\text { Reliability }\end{array}$ & .89 \\
\hline
\end{tabular}

Comparison between the Organisation Mean $\left(\beta_{\text {mean }}\right)$ and Item Mean $\left(\mu_{\text {mean }}\right)$ measures should be able to determine whether the instrument had sufficient items to measure the organisations' current awareness level on competitiveness in the Malaysian construction industry. The slight difference between the Organisation Mean ( $\beta_{\text {mean }}=+1.65$ logit; $S D=+2.06$ logit) and the Item Mean $\left(\mu_{\text {mean }}=0.00\right.$ logit; $S D$ $=+0.71$ logit) indicated a strong match between the person and item locations. It explained that the items below an organisation's level had a greater probability of being endorsed, while items above an organisation's level had a lower probability of being endorsed (Bond and Fox, 2007).

Overall, this showed that the items in the questionnaire survey had fulfilled the criteria in identifying the current awareness level and investigating the important attributes of awareness of local contractors on competitiveness in the Malaysian construction industry. Furthermore, it showed a good indication of the goodness of fit of the questionnaire survey, which measured what has to be measured in the underpinning theory and hence contributing to its validity.

\section{Analysis on Organisations}

In Rasch analysis, the organisations are arranged in measure according to their ability in endorsing the items based on difficulties of the items in the logit scale. The maximum organisation ability was $\beta_{\max }=+4.66$ logit and the minimum measure was $\beta_{\min }=-3.78$ logit. The separation statistic for the organisation was 4.89 , indicating that 61 respondents were generally separated into three groups. The organisation mean $\beta_{\text {mean }}=+1.65$ logit gave the indication that the respondents had the ability to agree on most of the awareness as shown in Figure 6. The locations for 61 organisations are on the left side of the vertical line while the right side of the vertical line represents the 21 items. 


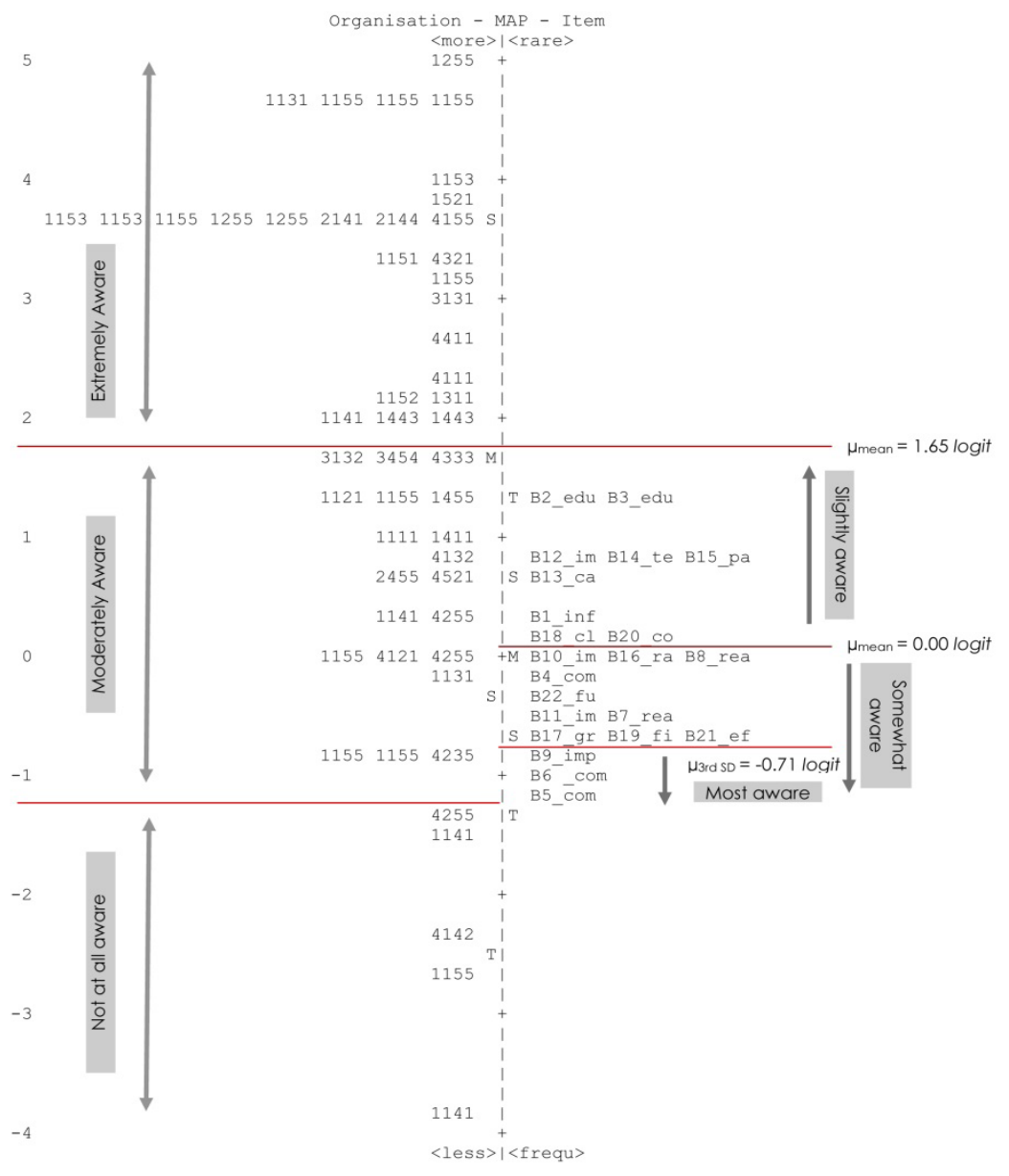

Figure 6. Organisation-Item Distribution Map

\section{Analysis on Items}

The maximum item ability was $\mu_{\max }=+1.39$ logit and the minimum measure was $\mu_{\min }=-1.11$ logit. The separation statistic for items was 2.61 , indicating that the 21 items were generally separated into three groups, labelled as items that respondents found very difficult as shown in Figure 6. All the 21 items were sorted based on the level of enforceability of an item based by the respondents in logit unit as shown in Table 6. 
Table 8. Level Enforceability of an Item by the Respondents

\begin{tabular}{|c|c|c|}
\hline $\begin{array}{c}\text { Category/ } \\
\text { logit }\end{array}$ & Code & Description \\
\hline \multirow{9}{*}{$\begin{array}{l}\text { Slightly } \\
\text { aware } \\
(0.01 \text { to } \\
1.65)\end{array}$} & B3 & $\begin{array}{l}\text { Local contractors are seen to attend any education programs by } \\
\text { non-government to increase knowledge on FTA. }\end{array}$ \\
\hline & B2 & $\begin{array}{l}\text { Local contractors are seen to attend any education programs by } \\
\text { government to increase knowledge on FTA. }\end{array}$ \\
\hline & B12 & $\begin{array}{l}\text { Local contractors implement competitive strategy in competing } \\
\text { with foreign contractors. }\end{array}$ \\
\hline & B15 & $\begin{array}{l}\text { Local contractors form strategic partnerships with multinational } \\
\text { companies (MNCs) and government linked companies (GLCs) to } \\
\text { gain access to local and international markets. }\end{array}$ \\
\hline & B14 & $\begin{array}{l}\text { Local contractors more aware of technological changes occurring } \\
\text { outside the industry that can be applied to competing in it. }\end{array}$ \\
\hline & $\mathrm{B} 13$ & $\begin{array}{l}\text { Local contractors focus on improving competitiveness in the } \\
\text { capability and capacity to venture internationally. }\end{array}$ \\
\hline & B1 & Local contractors have adequate information on FTA in Malaysia. \\
\hline & B20 & $\begin{array}{l}\text { Local contractors develop an awareness of the primary importance } \\
\text { of competitive strategy in pursuit of competitive advantage. }\end{array}$ \\
\hline & B18 & Local contractors classify the types of competition that they face. \\
\hline \multirow{9}{*}{$\begin{array}{l}\text { Somewhat } \\
\text { aware } \\
(-0.72 \text { to } \\
0.00)\end{array}$} & B8 & $\begin{array}{l}\text { Local contractors increase level of readiness in competing with } \\
\text { foreign contractors locally. }\end{array}$ \\
\hline & B16 & $\begin{array}{l}\text { Local contractors raising the awareness of the benefit of new } \\
\text { knowledge, technology availability in the market, and improving } \\
\text { the accessibility of new knowledge. }\end{array}$ \\
\hline & B4 & $\begin{array}{l}\text { Local contractors identify competitiveness of competitor } \\
\text { characteristics when bidding new projects. }\end{array}$ \\
\hline & B22 & $\begin{array}{l}\text { Local contractors are aware of the fundamental role played by } \\
\text { innovation in achieving competitive success. }\end{array}$ \\
\hline & B11 & $\begin{array}{l}\text { Local contractors implement competitive strategy in competing } \\
\text { with other local contractors. }\end{array}$ \\
\hline & B7 & $\begin{array}{l}\text { Local contractors increase level of readiness in competing with } \\
\text { other local contractors locally. }\end{array}$ \\
\hline & B17 & $\begin{array}{l}\text { Awareness by local contractors about the competitiveness of their } \\
\text { competitor is growing. }\end{array}$ \\
\hline & B19 & $\begin{array}{l}\text { Local contractors are aware of the fierce competition that other } \\
\text { local and foreign contractors would give them in Malaysia when } \\
\text { more market liberalisation takes place. }\end{array}$ \\
\hline & B21 & $\begin{array}{l}\text { Local contractors are aware of the importance of effective } \\
\text { implementation of strategy in improving competitiveness. }\end{array}$ \\
\hline \multirow{3}{*}{$\begin{array}{l}\text { Most } \\
\text { aware } \\
(-1.42 \text { to } \\
-0.71)\end{array}$} & B9 & $\begin{array}{l}\text { Local contractors improve competitiveness in competing with other } \\
\text { local contractors locally. }\end{array}$ \\
\hline & B6 & $\begin{array}{l}\text { Local contractors identify competitiveness of competitor } \\
\text { weaknesses when bidding new projects. }\end{array}$ \\
\hline & B5 & $\begin{array}{l}\text { Local contractors identify competitiveness of competitor strength } \\
\text { when bidding new projects. }\end{array}$ \\
\hline
\end{tabular}

All presented item measures provided an initial impression about the location of the items in the continuum scale. Items with positive (+ve) measures were harder to endorse or where the respondents were not really aware on the important attributes of awareness, while items with negative (-ve) measures were easier to endorse or 
where the respondents were more aware on the important attributes of awareness items.

As shown in Table 6, item B5 (local contractors identify competitiveness of competitor strength when bidding new projects) located at the bottom of the table in the Most Important Attributes of Awareness category is considered as the easiest item to endorse with a score of -1.11 logit while the most difficult item to endorse is item B3 (local contractors are seen to attend any education programmes by nongovernment to increase knowledge on FTA) located at the top of Table 6 with a score of +1.39 logit in the Slightly Important Attributes of Awareness items category. In general, the results showed a good item fit for all the items, which in turn showed a good indication that the scale fitted the Rasch model.

\section{DISCUSSION}

The findings of this paperidentified that most of the contractors have the awareness of competitiveness in the Malaysian construction industry. This showed that contractors in Malaysia realise the importance and impact of competitiveness for the Malaysian construction industry's survival. This is supported by Shen et al. (2003) who claimed that the identification of contractors' strengths and weaknesses would make the contractors become more competitive. It indicated that the local contractors can face the competition due to liberalisation and globalisation in the Malaysian construction industry if the importance, impacts, strengths and weaknesses are discussed via educational programmes conducted. Contractors need to improve their competitiveness, so that they can secure their position in competing with other contractors. Therefore, this paper argues on the mechanism from the government to give the information about competitiveness to the contractors. This can be explained more on the difficult items to be discussed in succeeding, which are the items B3 (local contractors are seen to attend any education programme by nongovernment to increase knowledge on FTA) and B2 (local contractors are seen to attend any education programmes by government to increase knowledge on FTA).

On the other hand, there were three items in the most important attributes of awareness category, which were B5 (local contractors identify competitiveness of competitor strength when bidding new projects), B6 (local contractors identify competitiveness of competitor weaknesses when bidding new projects) and B9 (local contractors improve competitiveness in competing with other local contractors locally).

For items B5 and B6, it is shown that the local contractors carry out the strength, weakness, opportunity and threat (SWOT) analysis of their competitor in competing with them. This eventually shows that the local contractors have the capability to compete with other contractors, be it local or foreign contractors in the Malaysian construction industry. Wang, XU and Li (2009) conducted a study on the decision criteria of the bid or no bid tendering projects, which showed whether a project can be acquired and the contractor have to give up on the projects if their competitors are much stronger than their company. Competitor's strength is a qualitative indicator of the competitor which includes their strong market share, design capability, risk control capability and experience of the similar type of projects. Enshassi, Mohamed and Karriri (2010) further explained that the contractors' bidding decisions are affected by external factors such as the number 
of the competitors, the strength of the competitor, the stability of the construction industry, government policy and others.

Therefore, identification of the weaknesses of the competitors will give benefit to the local contractors, where the contractors can utilise the competitors' weaknesses and turn it as strength to their company. Identifying the weaknesses of the competitor is one of the systematic analysis of the competitor and the contractor can acquire knowledge to gain and maintain their competitive advantage (Bose, 2008). Tung (2012) agreed that a company takes the chance to gain advantage from its strength and takes opportunity from their competitors' weaknesses.

Other important items on the most important attributes of awareness category was local contractors improve competitiveness in competing with other local contractors locally. Yu (2003) suggested that examining the competitive advantage and disadvantage of local contractors compared to the foreign contractors in the local market will improve the competitiveness of the local construction industry. It can be applied on local contractors in competing with other local contractors in the Malaysian construction industry. Suresh and Egbu (2007) further explained that knowledge gaining is one of the strategies in improving competitiveness. Despite working in the local construction industry, Lu et al. (2009) suggested that the contractors can improve competitiveness by venturing overseas project by exploring the global market, exploiting the global resources as well as learning new technologies or business operation from their foreign partner.

Referring to difficult items or slightly important attributes of awareness items by the local contractors in competitiveness, the most difficult item recorded was B3 (local contractors are seen to attend any education programme by nongovernment to increase knowledge on FTA), where it seemed that they do not attend these programmes due to insufficient education programmes on the awareness of competitiveness in the Malaysian construction industry conducted by the non-government agencies. Similar results were recorded by the second most difficult item, which was B2 (local contractors are seen to attend any educational programme by the government to increase knowledge on FTA). This demonstrated that educational programme on the awareness of competition in the Malaysian construction industry is insufficiently conducted by the Malaysian government, hence the local contractors are not aware of the educational programme conducted by the responsible agencies. This is further supported by CIDB who conducted a survey analysis on the Seminar on Trans-Pacific Partnership Agreement (TPPA) on 2013 (CIDB, 2013) which TPPA is one of the FTA initiatives involving 12 countries, Australia, Brunei, Canada, Chile, Malaysia, Mexico, New Zealand, Peru, Singapore, United States, Vietnam and Japan. The result of the survey analysis showed that none of the participants agree on the government consultation with industry stakeholders prior to TPPA, hence the government has to conduct more educational programmes to provide better understanding on the agreement. Alsanad, Gale and Edwards (2011) also suggested that in order to increase the level of awareness and knowledge, educational programmes such as training courses, conferences, seminars, study tour, public announcement and workshops have to be conducted.

The third most difficult item was B 12 (local contractors implement competitive strategy in competing with foreign contractors). It showed that local contractors have to struggle to compete with foreign contractors in the Malaysian construction industry. This might be because of the lack of experience in competing with the foreign contractors due to the fact that although the international local Malaysian 
contractors started venturing overseas since 1986, the number of projects secured by the Malaysian contractors overseas keeps decreasing by looking at the number of ongoing projects compared to the number of completed projects (CIDB, 2016b). Hashim (2012) asserted that this is due to the lack of experience in international business, where companies focusing on working in the local market will feel the fierce competition from foreign companies working in that same market. Abidin, Adros and Hassan (2014) suggested that with the increased competitive environment, effective competitive strategy can help the company to secure its position.

\section{CONCLUSION}

Within the context of this study, competitiveness can be referred to as the willingness of contractors to compete and their ability to design and deliver projects better than offered by their competitors. This study adopted a quantitative approach using a self-administered questionnaire survey. Using a sampling frame provided by CIDB Malaysia, 61 Grade 7 Malaysian contractors have responded to indicate their level of awareness on competitiveness in the Malaysian construction industry. Rasch Model analysis was used to determine the most important attributes of local contractors in competing with both local and foreign contractors in the Malaysian construction industry. The findings provided a baseline for the Malaysian local contractors to enhance their moderate level of competitiveness by engaging in various educational programmes such as training courses, conferences, seminars, study tour, public announcement and workshops conducted by the responsible agencies. These will equip them when bidding for new projects and secure their positions in competing with both local and foreign contractors in the increased competitive environment. Finally, this study has contributed to the body of knowledge in the international construction business for contractors to build their readiness to face the fierce globalisation and liberalisation happening in both the local and international markets. For future studies, the factors contributing to the competitiveness of local contractors in the Malaysian construction industry should be investigated. There is also a limitation in this paper where the sample size is small because the total population is taken only from the local contractors who have ventured into overseas projects. It would be fruifful to get different responses from the other local contractors who have not ventured overseas because they are also facing competition with foreign contractors in the Malaysian construction industry.

\section{ACKNOWLEDGEMENTS}

The authors would like to express their sincere gratitude to the Ministry of Education Malaysia, Universiti Teknologi Malaysia (UTM) and the Research Management Centre (RMC) of UTM for providing the financial support for this paper to be published. This study is financed by the Grant for Research University (GUP) Tier 1 of UTM for research funding under Cost Centre No. KI30000.2540.11 H09. 


\section{REFERENCES}

Ab Rani, N.I., Mat Isa, C.M. and Preece, C.N. (2015). Development of Foreign Competitor Identification Index (FCII) in Malaysia. Information Management and Business Review, 7(1): 12-22.

Abidin, N.Z., Adros, N.A. and Hassan, H. (2014). Competitive strategy and performance of quantity surveying firms in Malaysia. Journal of Construction in Developing Countries, 19(2): 15-32.

Alsanad, S., Gale, A. and Edwards, R. (2011). Challenges of sustainable construction in Kuwait: Investigating level of awareness of Kuwait stakeholders. Engineering and Technology, 59: 2197-2204.

Baghaei, P. (2008). Transactions of the Rasch measurement SIG the Rasch model as a construct validation tool. Rasch Measurement Transaction, 22(1): 1145 1146.

Bergen, M. and Peteraf, M.A. (2002). Competitor identification and competitor analysis: A broad-based managerial approach. Managerial and Decision Economics, 23(4-5): 157-169.

Bond, T.G. and Fox, C.M. (2007). Applying the Rasch Model: Fundamental Measurement in the Human Sciences. 2nd Ed. New Jersey: Lawrence Erlbaum Associates, Inc.

Bond, T.G. and Fox, C.M. (2001). Applying the Rasch Model: Fundamental Measurement in the Human Sciences. 1st Ed. New Jersey: Lawrence Erlbaum Associates, Inc.

Bose, R. (2008). Competitive intelligence process and tools for intelligence analysis. Industrial Management and Data Systems, 108(4): 510-528.

Chaiprasit, S. and Swierczek, F.W. (2011). Competitiveness, globalization and technology development in Thai firms. Competitiveness Review: An International Business Journal, 21 (2): 188-204.

Construction Development Board (CIDB). (2016a). Contractor Registration Requirements and Procedures. Kuala Lumpur: CIDB.

. (2016b). Overseas Project Undertaken by Malaysian Contractors. Kuala Lumpur: CIDB. Available at: http://apps.cidb.gov.my/international/

(2014). Opportunities and Challenges in Services: Liberalisation in Construction and Professional Construction and Related Engineering Service. Kuala Lumpur: CIDB.

. (2013). Seminar on Trans-Pacific Partnership Agreement (TPPA). Kuala Lumpur: CIDB.

Costa, J., Singh, S. and El-Diraby, T.E. (2006). How do contractors evaluate company competitiveness and market attractiveness? The case of Toronto contractors. Canadian Journal of Civil Engineering, 33(5): 596-608.

Dlungwana, W.S. and Rwelamila, P.D. (2004). Contractor development models that meet the challenges of globalisation: A case for developing management capability of local contractors. Paper presented at the International Symposium on Globalisation and Construction. Bangkok, Thailand, 17-19 November.

Enshassi, A., Mohamed, S. and Karriri, A.E. (2010). Factors affecting the bid/no bid decision in the Palestinian construction industry. Journal of Financial Management of Property and Construction, 15(2): 118-142. 
Economic Planning Unit (EPU) (2015). Eleventh Malaysia Plan 2016-2012 Anchoring Growth on People. 1st Ed. Kuala Lumpur: Percetakan Nasional Malaysia Berhad.

Fisher, W.J. (2007). Rating Scale Instrument Quality Criteria. Rasch Measurement Transaction, $21(1): 1095$.

Hashim, F. (2012). Challenges for the internationalization of SMES and the role of government: The case of Malaysia. Journal of International Business and Economy, 13(1): 97-122.

Henricsson, J.P., Ericsson, S., Flanagan, F. and Jewell, C.A. (2004). Rethinking competitiveness for the construction industry. In F. Khosrowshahi (ed.), 20th Annual ARCOM Conference. Vol. 1. Reading, UK: Association of Researchers in Construction Management (ARCOM), 335-342.

Huang, J.H. and Peng, K.H. (2012). Fuzzy Rasch model in TOPSIS: A new approach for generating fuzzy numbers to assess the competitiveness of the tourism industries in Asian countries. Tourism Management, 33: 456-465.

Hussain, A.H., Khairi, M., Husain, A., Irfan, A., Ani, C., Irza, N. and Ali, Z.M. (2015). Unlocking the potential value of BIM implementation in Malaysia: A pilot study. European Journal of Advances in Engineering and Technology, 2(12): $11-20$.

Intezar, M.T., Alotaibi, K.A. and Abdallah, A.S.R. (2016). Patients' satisfactions from public hospitals services in Alkharj and Hotat Bani Tamim: A comparative study. Asian Social Science, 12(5): 167-178.

Kamal, E.M. and Flanagan, R. (2012). Understanding absorptive capacity in Malaysian small and medium sized (SME) construction companies. Journal of Engineering, Design and Technology, 10(2): 180-198.

Krejcie, R.V. and Morgan, D.W. (1970). Determining sample size for research activities. Educational and Psychological Measurement, 30: 607-610.

Li, L., Li, D. and Dalgic, T. (2004). Internationalization process of small and mediumsized enterprises: Toward a hybrid model of experimental learning and planning. Management International Review, 44(1): 93-116.

Linacre, J. (2002). What do infit and outfit, meansquare and standardized mean? Rasch Measurement Transactions, 16(2): 878.

Ling, F.Y.Y. and Gui, Y. (2009). Strengths, weaknesses, opportunities and threats: Case study of consulting firms in Shenzhen, China. Journal of Construction Engineering and Management, 135(7): 628-636.

Lu, W., Li, H., Shen, L., Asce, M. and Huang, T. (2009). Strengths, weaknesses, opportunities and threats analysis of Chinese construction companies in the global market. Journal of Management in Engineering, 25(4): 166-176.

Lu, W., Shen, L., Asce, M. and Yam, M.C.H. (2008). Critical success factors for competitiveness of contractors: China study. Journal of Construction Engineering and Management, 134: 972-982.

Majid, S., Bakar, R.A., Sieh, L., Sieh, P. and Mei, L. (2004). Impact of AFTA on ACF Member Countries. Bangkok: ASEAN Construction Federation (ACF).

Ministry of International Trade and Industry (MITI) (2006). Third Industrial Master Plan (IMP3) 2006-2020 Malaysia towards Global Competitiveness. Kuala Lumpur: MITI.

Oo, B., Drew, D.S. and Runeson, G. (2010). Competitor analysis in construction bidding. Construction Management and Economics, 28(12): 1321-1329. 
Orozco, F.A., Serpell, A.F. and Molenaar, K.R. (2011). Factors and indexes for construction companies: Findings of Chile. Revista de La Construction, 10(1): 91-107.

Orozco, F.A., Serpell, A.F., Molenaar, K.R. and Forcael, E. (2014). Modeling competitiveness factors and indexes for construction companies: Findings of Chile. Journal of Construction Engineering and Management, 140: 1-13.

Othman, N., Salleh, S.M., Hussein, H. and Ab. Wahid, H. (2014). Assessing construct validity and reliability of competitiveness scale using Rasch model approach. In The 2014 WEI International Academic Conference Proceedings. Bali, Indonesia: West East Institute, 113-120. Available at: http://www. westeastinstitute.com/wp-content/uploads/2014/06/Suria-Mohd-Salleh.pdf

Pellicer, E., Yepes, V. and Rojas, R.J. (2010). Innovation and competitiveness in construction companies: A case study. Journal of Management Research, 10(2): 103-115.

Said, R.F.M. (2016). Application of Rasch measurement model in evaluating student performance for Foundation of Computing II. In C. Fook, G. Sidhu, S. Narasuman, L. Fong and S. Abdul Rahman (eds.). 7th International Conference on University Learning and Teaching (InCULT 2014) Proceedings. Singapore: Springer.

Scholten, A.Z. (2011). Admissible statistics from a latent variable perspective. PhD diss. University of Amsterdam.

Seaden, G. and Manseau, A. (2001). Public policy and construction innovation. Building Research and Information, 29(3): 182-196.

Sha, K., Yang, J. and Song, R. (2008). Competitiveness assessment system for China's construction industry. Building Research and Information, 36(1): 97-109.

Shan, L. (2010). Strategies for international construction related consultancy firms to compete in China. PhD diss. National University of Singapore.

Shen, L.Y., LU, W., Shen, Q. and Li, H. (2003). A computer-aided decision support system for assessing a contractor's competitiveness. Automation in Construction, 12(5): 577-587.

Sher, P.J. and Lee, V.C. (2004). Information technology as a facilitator for enhancing dynamic capabilities through knowledge management. Information and Management, 41: 933-945.

Suresh, S. and Egbu, C. (2007). The role of knowledge capture for improved competitiveness in small and medium enterprises in the UK construction industry: An empirical study. In Proceedings of the CIB W102 3rd International Conference: Information and Knowledge Management; Helping the Practitioner in Planning and Building. Stuttgart, Germany: Fraunhofer IRB Verlag, 194-203.

Tung, J. (2012). A study of product innovation on firm performance. International Journal of Organizational Innovation, 4(3): 84-97.

Wang, J., XU, Y. and Li, Z. (2009). Research on project selection system of preevaluation of engineering design project bidding. International Journal of Project Management, 27: 584-599.

Winch, G.M. (2000). Institutional reform in British construction: Partnering and private finance. Building Research and Information, 28(1): 141-155.

Wong, W.W. (2012). The internationalization of Malaysian engineering consulting services firms. DBA diss. Southern Cross University.

Yates, J.K. and Aniftos, S. (1997). Engineering and construction industry. Journal of Management in Engineering, 13(3): 31-39. 
Yean, F., Ling, Y., Min, V., Pham, C. and Hoang, T.P. (2009). Strengths, weaknesses, opportunities and threats for architectural, engineering and construction firms: Case study of Vietnam. Journal of Construction Engineering and Management, 135(10): 1105-1113.

Yu, L.W. (2003). A study of the competitiveness of local contractors in Hong Kong. PhD diss. Hong Kong Polytechnic University.

Yu, W.D., Cheng, S.T., Shie, Y.L. and Lo, S.S. (2006). Benchmarking technological competitiveness of precast construction through patent map analysis. In Proceedings of the International Symposium on Robotics and Automation in Construction, ISARC 2006. Tokyo: Waseda University, 118-123. https://doi. org/10.22260/ISARC2006/0025.

Zhao, Z.Y. and Shen, L.Y. (2008). Are Chinese contractors competitive in international markets? Construction Management and Economics, 26(3): 225-236. 